\title{
ポリエチレングリコール唀導体姏理岇酸カルシウムの ポリプロピレンへの充てん奻果*
}

\author{
光石 一太苂・児玉 総治*1 ・ 川崎 长士*1
}

(受付 1984 作 7 月 23 日・专査終了 1984 年 10 月 8 日)

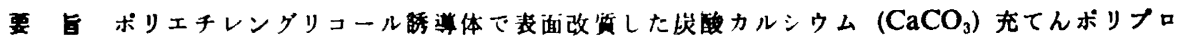
ピレン (PP) を作成した。そして複合体の引張破断伸び，粘弹性特性（强失正接）及び $\mathrm{PP} / \mathrm{CaCO}_{3}$

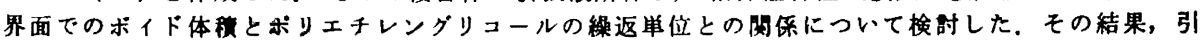
張破断伸び，主分散ビークの損失正接 $(\tan \delta)_{\max }$ は，絴返単位の增加に伴い増加したが，ボイド体 程は诚少した。さらに $(\tan \delta)_{\max }$ に及ほ十粒径依存性においては, $\mathrm{CaCO}_{8}$ の比表面程当たりの $(\tan$ $\delta)_{\max }$ は, $\mathrm{CaCO}_{3}$ (平均粒径 $1.0 \mu \mathrm{m}$ ) の方が $\mathrm{CaCO}_{3}(4.5 \mu \mathrm{m})$ に比へて诚少した。 これは $\mathrm{CaCO}_{3}$ 粒子表面に付曾している表面処理剂门童か原因と思われる。
\end{abstract}

\section{1 堵青}

ポリオレフィン材料には，無機フィラーが弾性率・勲 安定性の向上のため大量に充てんされている.しかし， ポリオンフィンと無フィラーは，界面での親和性に之 しく得整強度・延性特性の低下が大きいため，これらの デメリットの改善に対してフィラーの表面改貿がなれ

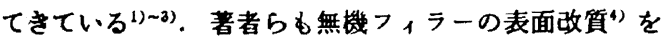
実施して扰り，前報》てではン酸系化合物で表面改質し た炭酸カルンウムをボリプロピレンに充てんしてその機 械的特性についてて検討してきた，今回は，表面改犋剂と してポリェチレンクリコール誘道体を取り上げた。 Kowaleski らの)はポリエチレンクリコールをポリエ チレンの樹脂改質剂として取扱っている。ここで、ポリ エチレンクリコールの添加量はフフィラーに対して $10 \mathrm{wt} \%$ と多く無釹〉ィラーの表面改質剂上りもむしろ ポリェチレンの榯脂改質の様相が強くなっている。この よらにポリェチレンタリコールを無機つィラーの表面改 質剂として取报われた例ははとんどなく、またボリエチ レンタリコールの結返単位を系統的に変化させ，その影 繁が機械的特性に及汪す効果については触れられていな い.

そこで本報告においてい，ボリエチレンクリコールの 綝返単位が表面改算炭酸カルシウム充てんポリプロピレ ンの機械的特性に及ぼす奻果について検討した．機械的

*本報を「粒子分散系複合材料に関十る研究第 2 報」とする。

*1 岡山県工業技術センター（两700 岡山市伊福町 43-18)
特性については，延性効果の把握のため引張破断伸びを 用い、またフィラー/表面改質郕/マトリックス間の相互 作用の検討のため粘弹性特性を用いた。

\section{2 实験方法}

\section{1 材料}

高分子基材は、フインタクチックポリプロピレン (PP, 昭和龟工(株) 製ショーアロマ), 充てん剂は Table 1 に示す上5に備北粉化工業(株) 製重質炭酸カルシウム $\left(\mathrm{CaCO}_{3}\right)$ で粒径の異なる二つのタイブを用いた。 また

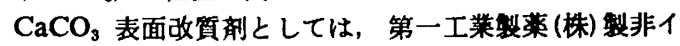
オン系ボリエチレンクリコール誘導体 $\mathrm{C}_{0} \mathrm{H}_{10}\langle\underline{O}\rangle-\mathrm{O}$ $\left.+\mathrm{CH}_{2} \mathrm{CH}_{2} \mathrm{O}\right)_{n} \mathrm{C}-\mathrm{CH}=\mathrm{CH}_{2}$ (以下, $\mathrm{PEG} n$ とする. $n$ O

はポリエチレンクリコールの綝返戦位) を用いた。本実 験では， $n=13 ， 16 ， 22 ， 40$ とした。この際 $n=16$ は, 市肘品であるが他のものについては試作した.

\section{2 試料の作成}

2.2.1 $\mathrm{CaCO}_{3}$ の表面改留 $\mathrm{CaCO}_{3}$ は, 初めに前処 理として $105^{\circ} \mathrm{C}, 72 \mathrm{~h}$ の熱風䫧燥を実施した。続いて, エタノール $500 \mathrm{ml}, \mathrm{CaCO}_{3} 100 \mathrm{~g}$ PEGn $1 \mathrm{~g}$ をナス型 フラスコに入れ、ロータリ型エハホホレータを用いて温水 中 $\left(50 \pm 2^{\circ} \mathrm{C}\right)$ で真空びきをしながら $\mathrm{CaCO}_{3}$ の表面改 質を実施した，表面改質 $\mathrm{CaCO}_{3}$ は， $100^{\circ} \mathrm{C} 48 \mathrm{~h}$ 熱風 畭燥を行った．また PEGnを添加させずに同一処理を

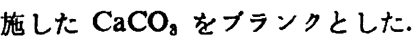

2.2.2 物性测定用煁料の作成 ロール混練は, Table 2 に示す配合割合により電熱ロール機を用いてロール表 
Table 1. Properties of $\mathrm{CaCO}_{3}$

\begin{tabular}{llcc}
\hline & & $\mathrm{CaCO}_{3}(\mathrm{~A})$ & $\mathrm{CaCO}_{3}(\mathrm{~B})$ \\
\hline Particle size & $(\mu \mathrm{m})$ & 4.5 & 1.0 \\
Surface area & $\left(\mathrm{m}^{2} / \mathrm{g}\right)$ & 3.1 & 6.0 \\
Density & $\left(\mathrm{g} / \mathrm{cm}^{3}\right)$ & 2.7 & 2.7 \\
\hline
\end{tabular}

Table 2. The amount of PEGn agents adhering on the $\mathrm{CaCO}_{3}{ }^{\mathrm{a}}$ )

\begin{tabular}{lcc}
\hline$n$ & $\mathrm{CaCO}_{8}(\mathrm{~A})$ & $\mathrm{CaCO}_{3}(\mathrm{~B})$ \\
\hline 13 & 0.57 & 0.62 \\
16 & 0.61 & 0.65 \\
22 & 0.62 & 0.54 \\
40 & 0.60 & 0.59 \\
\hline
\end{tabular}

') $\left(\mathrm{g} / \mathrm{CaCO}_{3} 100 \mathrm{~g}\right)$

面温度 $180 \pm 5^{\circ} \mathrm{C}$, 混練時間 $8 \mathrm{~min}$ で行った。混綀試料 は，単動式圧摍成型機において 金型温度 $230 \pm 5^{\circ} \mathrm{C}, 5$ min の予熱ののち、 ゲージ压力 $150 \mathrm{kgf} / \mathrm{cm}^{2} 5 \mathrm{~min}$ 加 匤し， $20 \mathrm{~cm} \times 17 \mathrm{~cm} \times 0.03 \mathrm{~cm}$ の成型板とした，成型 板は，冷ブレスルより急冷処理を施し物性測定用試料と した.

\section{3 物性测定}

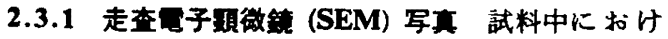
る $\mathrm{CaCO}_{3}$ の分散状態は，引張衡盤した破面に金蒸着を 施し，X線マイクロアナライザー (EPMA，日本電子 (株)）にて叟察した。

2.3.2 引張特性 引張試筷は、オートタラフ 500-S (島津製作所(株) 製) により温度 $23 \pm 1^{\circ} \mathrm{C}$, 湿度 $65 \pm$ $2 \%$, 引張速度 $50 \mathrm{~mm} / \mathrm{min}, チ+ッ ク$ 間隔 $7 \mathrm{~cm}$ の测 定条件で実施した. 引張特性の評価は，次に示すよ5に チャック間隔の伸びから相対引張破断伸び $\left(T_{z}\right)$ として 整理した。

$$
\begin{aligned}
& T_{\mathrm{r}}=T_{\mathrm{B}} / T_{\mathrm{PB}} \\
& T_{\mathrm{B}} \text { : 各種武料の引張破断伸び (\%) } \\
& T_{\mathrm{PB}}: \mathrm{PP} \text { 陚料の引張破断伸び }(\%)
\end{aligned}
$$

たたし $T_{\mathrm{B}}=\left(l-l_{0}\right) / l_{0} \times 100, \quad T_{\mathrm{PB}}=\left(l-l_{0}\right) / l_{0} \times 100$

$l_{0}$, 延伸前のチャック間 $(\mathrm{cm})$.

$l$, 破断時のチ+ック間陆 $(\mathrm{cm})$.

2.3.3 粘弹性特性 動的粘弹珄の 測定は，粘弾性ス ベクトロメータVES-S (岩本製作所(株) 辢) を用いた。 $\mathrm{CaCO}_{\mathrm{a}}$ 充てん PP の温度分散は, 試料長 $3 \mathrm{~cm}$, 武料 幅 $0.4 \mathrm{~cm}$, 周波数 $50 \mathrm{~Hz},-20 \sim 130^{\circ} \mathrm{C}$ の温度领域の もとに $2^{\circ} \mathrm{C}$ 扰きに損失正接 $(\tan \delta)$ を測定した.

\section{3 英駼轺果及び考寮}

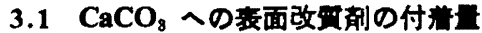

Table 2 には，エパポレーターを用いて表面改页した $\mathrm{CaCO}_{3}$ に付着している $\mathrm{PEG} n$ の重量を示した. $\mathrm{CaCO}_{3}$
Table 3. Filler volume fraction and PEG $n$ treated agents $^{\text {a) }}$

\begin{tabular}{ccc}
\hline Added PP & Added $\mathrm{CaCO}_{3}$ & Treated agent \\
\hline 1.0 & - & - \\
0.9 & 0.1 & - \\
0.85 & 0.15 & - \\
0.8 & 0.2 & - \\
0.9 & 0.1 & PEG $n$ \\
0.85 & 0.15 & PEG $n$ \\
0.8 & 0.2 & PEG $n$ \\
\hline
\end{tabular}

a) volume fraction.

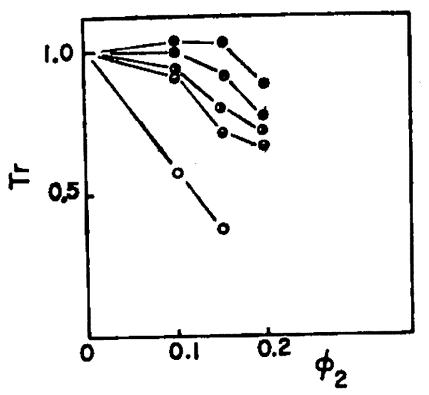

Fig. 1. Changes of maximum relative elongation $\left(T_{\mathrm{r}}\right)$ with volume fraction of filled $\mathrm{CaCO}_{3}\left(\phi_{2}\right)$ in PP: ๑, T40PP; $\ominus$, T22PP; 1, T16PP; $\ominus$, T13PP; O, NPP. $\mathrm{CaCO}_{3}$ (B)

(A) 人の付着量は，0.57 0.61 (g) と添加した $\mathrm{PEGn}$ に対して6 割程度であった。 また $\mathrm{CaCO}_{3}$ (B) Kつたて

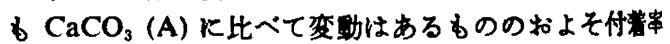
は 6 割前後であった，このよらに粒径及び PEGnの 返単位が変化してす $\mathrm{CaCO}_{3}$ への $\mathrm{PEGn}$ の付着量の差

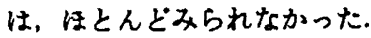

\section{2 引崛硪断伸ひ}

$\mathrm{CaCO}_{3}$ 充てん PP の引張破断伸びについては,

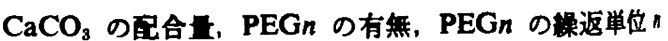

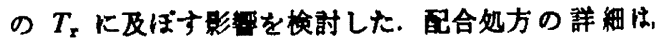
Table 3 に示才. Fig. 1 は, $\mathrm{CaCO}_{3}$ の体分分率 $\left(\phi_{2}\right)$ と $\mathrm{CaCO}_{3}$ 充てん $\mathrm{PP}$ の $\mathrm{T}_{\mathbf{x}}$ との成保を示したるのて ある. 末処理系 $\mathrm{CaCO}_{3}$ 充てん PP (以下, NPP と†

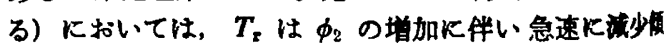
向にある.このことは、フィラートトリックス界面で 密着性が覀く，伸㲀にあたり界面でのはく䧼が著しい とを示咬している. 一方, PEGn 処理 $\mathrm{CaCO}_{3}$ (以下, TnPP とする) Kおいては， $\phi_{2}$ の増加に対してNPP はどの $T_{\Sigma}$ の低下はみられなかった. Fig. 2 には， $\operatorname{TnPP}$ の $T_{\varepsilon}$ と PEGn の綝返単位 $n$ との图俰を示した

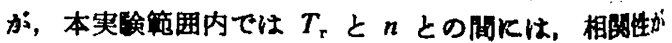
認められ， $T_{x}$ は $n=40$ の場合が取る大きかった。た 
ポリェチレングリコール䚞導体处理炭酸カルシウムのポリプロピレンへの充てん奻果

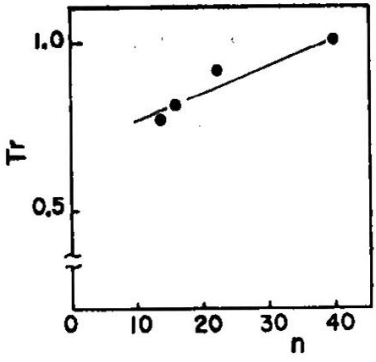

Fig. 2. Maximum relative elongation $\left(T_{\mathrm{r}}\right)$ for various numbers of repeating units of poly (ethylene glycol) $n$ : $\phi_{2}=0.15 ; \mathrm{CaCO}_{3}$ (B).

らの原因としては， $\mathrm{CaCO}_{3}$ に付着している $\mathrm{PEG} n$ の差 に基つく $\mathrm{CaCO}_{3}$ と PP との界面親和性とその結果生ず る分散性の影签が考えられる。

\section{$3.3 \mathrm{CaCO}_{3}$ と PP との瀗費性}

$\mathrm{CaCO}_{3}$ 充てん PP に対して延伸を加えると $\mathrm{CaCO}_{3}$ とPP との界面にボイドが発生する.そこで界面での密 着性の比校のため、試料の見掛けの延伸倍率を一定 (6 倍) にして，延伸に伴5体皘增加率 $\left(V / V_{0}\right)$ を測定 し た.ここで $V_{0}$ は，延伸前の試料の体積とし，Vは 6 倍延伸後の武料の体積とする. PP, TnPP, 及び NPP の延伸による $\left(V / V_{0}\right)$ は，PP, 1.02; T13PP, 1.52; T16PP, 1.53; T22PP, 1.48; T40PP, 1.43 及び NPP, $1.58\left(\phi_{2}, 0.2\right)$ となり PEGn の n が增加するほど $(V /$ $V_{0}$ ) の値が低下し，フィラー/トリックス界面でのは く離が卯制されていることを示している.ささらに Fig. 3 は、NPP 及び T40PP の引張衝撃破断面の SEM 写真 を示したるのである．NPP においては，破断面が平坦 で $\mathrm{CaCO}_{3}$ 粒子の PP マトリックスからの離脱が認め られる. T40PP は,フィラーマトリックス界面での空 げきが比䑤的少なくNPP に比べて起伏に富んだ表面形 態をしており表面処理効果が破断面からもらかがえる。

\section{4 粘弾性特性}

高分子基材に無機 フィラーを配合するとフィラー/マ トリックス界面及びフィラー粒子間の相互作用か慟くこ とが一般的に知られている. Fig. 4 は, TnPP の $\tan \delta$ 一温度曲線に打ける主分散ピークの極大值 $(\tan \delta)_{\max }$ とnの関俰を示したすのである. $(\tan \delta)_{\max }$ は，本実験 範囲内に打いて $n$ の增加に伴い增加する傾向にあった. このことは， $\mathrm{CaCO}_{3}$ への $\mathrm{PEG} n$ の付着量が $n$ の值に かかわらず一定であることを考虑に入れると，PEGnの 分子量が $(\tan \delta)_{\max }$ K対して寄与が大きいことを示哇 するすのである.

次に PP/PEGn の界面親和性に関する知見を得る意味 で PEGn 処理 $\mathrm{CaCO}_{3}$ の溶媒中に抢ける分散性を測定 した. Fig. 5 は， PEGn 処理 $\mathrm{CaCO}_{8}$ の沈降体積を溶

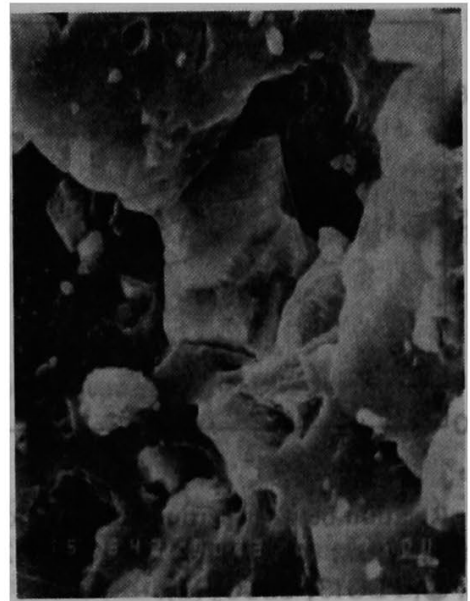

(a)

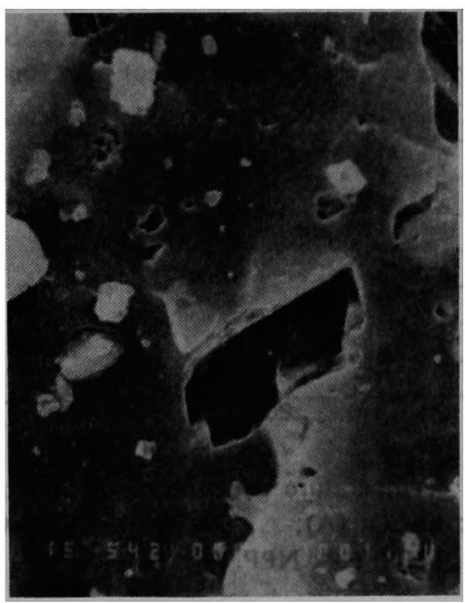

(b)

Fig. 3. Scanning electron micrograph of composites: $\phi_{2}=0.1, \mathrm{CaCO}_{3}$ (A); (a), T40PP; (b), NPP.

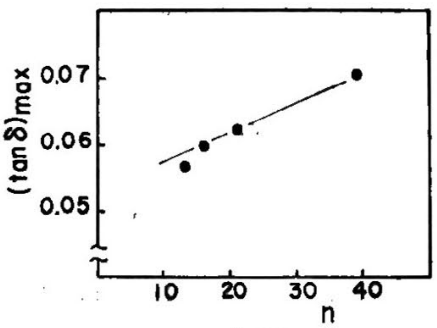

Fig. 4. Relation between $(\tan \delta)_{\max }$ and repeating unit $n: \phi_{2}=0.2 ; \mathrm{CaCO}_{3}(\mathrm{~A})$.

解度バラメーター (SP 值) の異なる非極性溶媒中（ $n$ ヘキサン, シクロへキサン, シクロペンタン, ペンゼ ン)について测定した結果である. PEG 40 処理 $\mathrm{CaCO}_{3}$ 


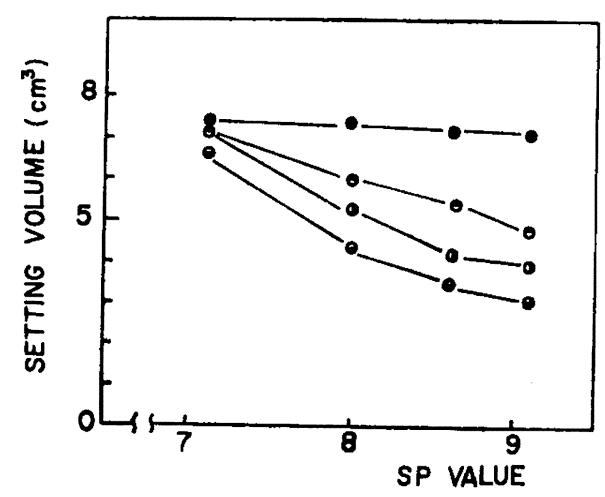

Fig. 5. Relation between setting volume and solubility parameters: $O$, PEG40; $\Theta$, PEG22; PEG16; $\odot$, PEG 13; $\mathrm{CaCO}_{3}$ (B).

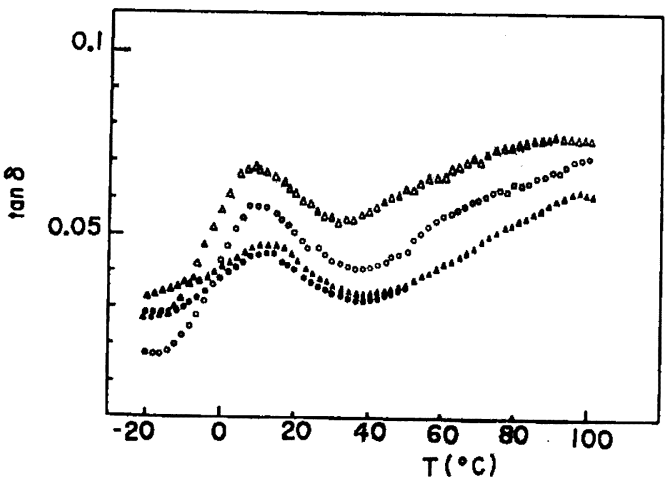

Fig. 6. Temperature dependence of loss tangent $(\tan \delta): \mathrm{CaCO}_{3}$ (A); $\triangle$, T40PP; $\triangle$, NPP. $\mathrm{CaCO}_{3}$ (B): $\bigcirc$, T40PP; O, NPP. $\phi_{2}=0.2$.

においては，沈降体積に及ぼす SP 值依存性はあまりみ られないか，他のすのについては $n=22,16,13$ の順 で沈降体程はSP 值の增加とともに徐々に滅少してい る. さらに PP と SP 值の同程度のシクロへキサン中 での $\mathrm{PEG} n$ 処理 $\mathrm{CaCO}_{8}$ の分散性については， $n$ が增 加するほど沈降体程は增加する傾向にあった。このよう に, シクロヘキサン/PEGn 処理 $\mathrm{CaCO}_{3}$ 分散系では, 沈降体䅡に及ぽす繰返単位 $\boldsymbol{n}$ の依存性が認められる点か らして, 系は異なるものの PP/PEGn 処理 $\mathrm{CaCO}_{3}$ の界 面親和性に対するnの影整か大をいことを示惨させる.

Fig. 6 は， NPP 及び T40PP の $\tan \delta$-温度曲線を 示したものである. T40PP の主分散ピークは, NPP に 比べてシャーブに現われるととるに $\tan \delta$ の值が大きく なる現象がみられた. NPP については， $\mathrm{CaCO}_{3}$ 充てん により温度依存性を受けない、 $\mathrm{CaCO}_{3}$ の平坦な分散の加 算並びに $\mathrm{CaCO}_{3}$ の分散珄不良に基つく分散曲線のブロ 一ド化の様相を呈している. T40PP では, PEG40 処理
Table 4. Relation between particle size and $(\tan \delta)_{\text {unlt }}$ (loss tangent per surface area of $\left.\mathrm{CaCO}_{3}\right)$

\begin{tabular}{ccc}
\hline & $\mathrm{CaCO}_{3}(\mathrm{~A})$ & $\mathrm{CaCO}_{3}(\mathrm{~B})$ \\
\hline T40PP & 22.0 & 9.8 \\
T22PP & 20.0 & 9.7 \\
$\mathrm{~T} 16 \mathrm{PP}$ & 19.3 & 9.4 \\
$\mathrm{~T} 13 \mathrm{PP}$ & 18.1 & 8.4 \\
$\mathrm{NPP}$ & 15.5 & 7.9 \\
\hline$\times 10^{-3}\left(\mathrm{~g} / \mathrm{m}^{2}\right)$ & &
\end{tabular}

による $\mathrm{PP} / \mathrm{CaCO}_{3}$ 間での相互の親利性向上に基づく分 散性の改善のため分散曲線がシャーブに現れたものと思 われる。

一方, $\tan \delta$ に及ぼす $\mathrm{CaCO}_{3}$ の粒径効果については, 次のように考えられる，粒径の異なる $\mathrm{CaCO}_{3}$ を充てん した NPP及び TnPP の $(\tan \delta)_{\max }$ を充てんした $\mathrm{CaCO}_{\mathrm{s}}$ の比表面除した值を $(\tan \delta)_{\text {anlt }}$ として Table 4 K示した. TnPP Kおいては, $\mathrm{CaCO}_{8}(\mathrm{~A})$ 及 び (B) 配合物の $(\tan \delta)_{\text {an1 }}$ は, NPP より增加する傎向

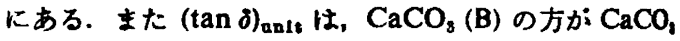
(A) 配合物に比べて減少し，粒径の羑が粘弾性特性に反 映していることが示されている.なお $\mathrm{CaCO}_{3}$ (B) 路 物の $(\tan \delta)_{\mathrm{unlt}}$ の增加が少なかった点については，炏 の点があげられる. ナなわち、 $\mathrm{CaCO}_{3}$ (B) 単位表面 当りへの $\mathrm{PEGn}$ の付着量か; $\mathrm{CaCO}_{3}$ (A) の半分程度て ある点並びに表面処理剂量の $(\tan \delta)_{\mathrm{anIt}}$ に対する传存 性については，その処理量が增大するほと增加する点が 粘弾性特性での粒径の差をむたらした要因と思われる.

要するに粘弾性特性に及ぼすポリェチレンクリコール

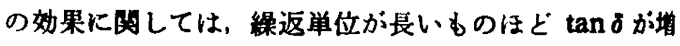

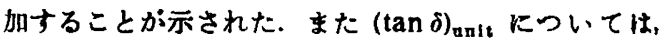
粒径の小さい方が娍少しているが，この原因としては $\mathrm{CaCO}_{8}$ 表面への $\mathrm{PEGn}$ の付着量の差畏が考えられる.

\section{4 洁 制}

炭酸カルシウム用表面改犋肪として，ボリェチレンタ

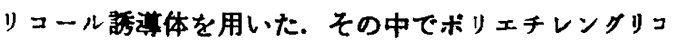
ールの繰返単位が表面改解酸カルシウム充てんポリフ ロビレンの引張特性, 粘弾性特性に及ぼす奻果について 検討した結果以下のことが明らかとなった。

1) 本実検䇴囲においては、ポリエチレンクリコール

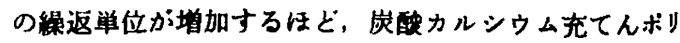
ブロピレンの引張破断伸び，主分散ピークの損失正接は 增加した.

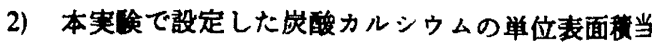
りの损失正接 $(\tan \delta)_{\text {anIt }}$ は，粒佳の小さいるの法ど 少する傾向にあった：これは，炭酸カルシウム表面に付 
着しているポリェチレングリコール誘通体の付着量の差 異が原因と考えられる。

\section{文部}

1）青木姰次郎，ポリマタイジェスト，32，52 (1980).

2）青木恂次郎，ポリマダィシェスト，36, 60 (1984).

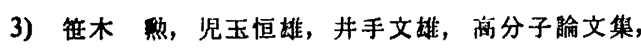
33, 162 (1976).

4) T. Nakatsuka, H. Kawasaki, and K. Itadani, J. Colloid Int. Sci., 82, 298 (1981).

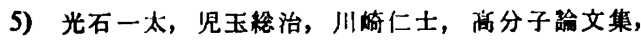
投稿中。

6) T. Kowaleski, J. Colloid Polym. Sci., 260, 652 (1982).

Polypropylene Filled with Calcium Carbonate and Treated with Poly(ethylene glycol) Derivatives*

Kazuta Mrtsuishi ${ }^{* 1}$, Soji Kodama*1, and Hitoshi KaWasaki ${ }^{* 1}$

* Studies on the Polymers Filled with Particles. II.

*1 Industrial Technology Center of Okayama Prefecture (3-18, Ifukucho 4-chome, Okayama, 700, Japan)

Polypropylene (PP) samples filled with calcium carbonate $\left(\mathrm{CaCO}_{3}\right)$, which have been treated with poly(ethylene glycol) derivatives (PEG), were prepared. The relationships between tensile ultimate elongation, viscoelastic property(loss tangent), void volume of $\mathrm{PP} / \mathrm{CaCO}_{3}$ surface of the composites and the repeating unit of PEG have been investigated. Maximum tensile elongation and loss tangent of primary dispersion peak ( $(\tan \delta)$ $\max$ ) increased with the increase of repeating unit, but void volume decreased with it. The effect of particle size on $(\tan \delta)$ max makes the value smaller for $\mathrm{CaCO}_{3}$ (mean size $1.0 \mu \mathrm{m}$ ) than for $\mathrm{CaCO}_{3}(4.5)$. This may result from differences of treatment agents which adhere on $\mathrm{CaCO}_{3}$.

KEY WORDS Polypropylene / Poly(ethylene glycol) Derivatives/Calcium Carbonate/Repeating Unit / Loss Tangent /

(Received July 23, 1984 : Accepted October 8, 1984)

[Kobunshi Ronbunshu, 42 (2), 129-133 (1985)] 